\title{
Connecting Learning Outcomes to Professional Life: Better Educational Policy for Better Professionals
}

\author{
Muhamad Taufik Hidayat ${ }^{1}$, Wahid Hasim², Asep Suparman ${ }^{3}$, Rajji K. Adiredja \\ \{mtaufikhidayat637@gmail.com ${ }^{1}$, wahidhasim2807@ gmail.com² \\ asep.suparman@institutpendidikan.ac.id $\left.{ }^{3}\right\}$ \\ Institut Pendidikan Indonesia, Jl. Terusan Pahlawan No.83, Garut $44151^{1}$, Institut Pendidikan \\ Indonesia, Jl. Terusan Pahlawan No.83, Garut $44151^{2}$, Institut Pendidikan Indonesia, Jl. Terusan \\ Pahlawan No.83, Garut $44151^{3}$
}

\begin{abstract}
Universities set graduate profiles and learning outcomes offered as the skills and knowledge to equip graduates for future education and employment. However, these profiles and learning outcomes may fail to lead their graduates to the expected results. The study is interested in discovering this singularity whether or not the graduate profiles and learning outcomes have met the expectations. Using survey and interviews, the study involved $100 \mathrm{EFL}$ university students and graduates in Indonesia as the participants. The results discovered that most EFL university students expected relevant career path to the graduate profile set by the university. However, the analysis on the graduates found that only fifty percent of the graduates undergo the profile-relevant careers. Those findings provide noteworthy feedback for the university and its stakeholders to revisit the graduate profiles and learning outcomes which in turn to readjust its educational policy to create better professionals for the ongoing and upcoming challenge.
\end{abstract}

Keywords: Educational policy, learning outcomes, professional life.

\section{Introduction}

A university is a place to prepare educated professionals. These professionals are prepared and educated to provide service and ensure quality according to their respective fields of expertise [1]. This area of expertise is reflected in the graduate profiles offered by each tertiary education. The graduate profiles are then distributed to a series of learning outcomes which become the standard abilities set by certain programs or departments. These learning outcomes are generally assembled based on the needs of the professional workforce.

However, most of the times, learning outcomes are the results of previous reviews or may sometimes be outdated. While the profesional life, described as the activities of a wide range of people across many occupational groups [2], is currently growing very rapidly and dynamically. There are voluminous needs that might have to be responded quickly by the world of education. To this end, the world of education is urged to adapt to these swift changes. Adaptation can be done if the world of education is sensitive to current and future developments. Reviewing graduate profile, curriculum, and learning outcomes on a regular basis should have been frequently carried out by universities.

This study associates the expectations and reality encountered by students and graduates about their future or actual professional life (careers) respectively. It is due to the fact that graduates and students are the main stakeholders defining the direction of education. By 
presenting their point of view, the world of education is expected to have a picture of the wishes of their "consumers". So that there will be an in line process between supply and demand in the world of education. It is expected to encourage the policy makers to provide better education to stimulate the creation of better professionals.

\section{Literature Review}

Education and the professional life are two attached realms. They both developed simultaneously and conjointly. It is due to the fact that the improvement of education is initially closely related to the needs of the workforce [3]. One the one hand, the working world demands higher levels of training and continuous refresher courses or retraining. On the other hand, the educational system is forced to adapt its teaching to the changing demands of the labor market [4]. Correspondingly, professional sector developed significantly as a result of the advancement in education. Human resources are improved and developed through education. Therefore, as someone chooses an area of education, he is basically compelled by the desire to well contribute in the field he chose. The immediate connection between professional life and education may be represented in learning outcomes as the guidelines for future career preparation. The motivation to make a career choice is reflected in the choice of the major. So it is somewhat unbiased when career and education are supposed to be synchronized.

The term career is defined as a long term commitment on the part of a person to seeking for advancement, through the status hierarchy that exists in their employment [5]. This leads to the social belief that good professional life should be prearranged as early as possible since it is likely to last in such a long period of time. However, what creates constructive career outcomes for university graduates is a multifaceted phenomenon. It was affected by numerous factors that come along with the transition from university life into the world of work [6]. Given to the fact, college or university is supposed to bridge this transition as a career choice is deemed an important decision for every individual [7] [8].

It was believed that there are three main concern in making a career decision; the financial benefits of employment, the chance to put theory and ideas gained on the course into practice, and job satisfaction [9]. The second concern is where education has a duty to function; preparing the students with necessary skill and knowledge required in the workplace. The immediate context possible in discussing education and professional life is university or college. Besides, schools are considered as one of the critical determinants in establishing appropriate career next to family's role [7]. Well-educated employees are favored by the workplace. It means that better education output manifested in better learning outcomes ensure better and longer career [10].Hence, aggregate survey responses collected from students are commonly used by universities to compare effective educational practices across program majors, and to make high-stakes decisions about the effectiveness of programs [11]. However, to certain extents, there is a high likelihood for discrepancy between students' initial perceptions and expectations of the profession and the workplace, and their actual experience [12]. Accrediting associations have raised expectations for institutions to collect evidence of student learning outcomes and use such information for institutional improvement [13]. 


\section{Research Method}

This survey study involved 100 participants. They were distributed into two categories; undergraduates (students) consisting of 20 male and 30 female and graduates (alumni) involving 24 female and 26 male alumni. The former were supposed to provide the information of the ideal career expectation when they graduate. On the other hand, the latter was expected to give the actual career realization they go through. Both come from the same university majoring in English Education. The involvement of the participants was largely based on some research concerns. The students were randomly selected to participate in this survey study. On the other hand, the alumni were chosen under certain conditions; they were eligible for the research provided that they are employees, employers and entrepreneurs. Unemployment was left out from the central consideration of this survey study. The career or profession categorization was limited to the careers consistent with the learning outcomes expected from the English education Department; teachers, translators, researchers, linguists and entrepreneurs. However, to accommodate other possible answers, "other" column was added.

\section{Finding and Discussion}

\subsection{Career expectations and realization}

To begin with, this study highlight the connection between learning outcome and future career by uncovering the undergraduate students' expectation on their career and learning outcomes. The students' expectation provide ideal information on what are they looking for and what they are trying to accomplish upon the completion of their study. This ideal expectation was also deemed a valuable input as students are one of the stakeholders in education.

Table 1 describes the survey result of the students' future career expectation. The expected careers they chose encircling the career relevant to their study. The survey discovered that most participants expected careers consistent with the knowledge and skills they learn. Table 1 shows that participants selected teachers, translators, linguists, researchers and other professions compliant with their fields of study. Similarly, when choosing entrepreneurship, the business they pursue is expected to be in accordance with the skills and abilities they learn. Twenty-three people $(46 \%)$ chose teachers or language instructors as their future career, three students dream of becoming translators $(6 \%)$, two students (4\%) want to become education or language researchers, three participants $(6 \%)$ dream of becoming language experts, three people $(6 \%)$ want to become entrepreneurs (travel or training agency) and the rest (the other 20\%) consider other employments related to their competence or learning outcomes. Based on the survey to the undergraduate students, nearly all participants think of or anticipate that their future professional life is supposed to be relevant to what they learn in the university. Thus, they believe the learning outcomes designated by the university should meet the upcoming challenges for their future employment. It means that the participating students are highly confident that their study will prepare themselves to become professionals. What follows are the description of the students' expectation for their upcoming professional life. 


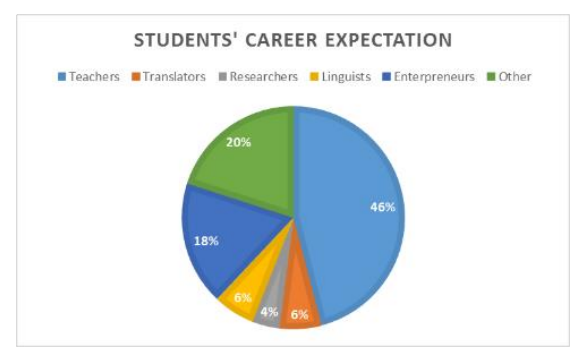

Fig1. Students' Professional Life Expectation

However, the survey on alumni career realization provides different perspectives on the relevance of learning outcomes and future careers. The results of this survey show an interesting singularity for it may presents thought-provoking data that is reasonably problematic. Unlike the students' expectations, the realization of alumni careers illustrates a rather different situation. From the description of graduate profiles available, teaching profession is literally dominating than other professions. This is illustrated in the following table describing the realization of alumni careers.

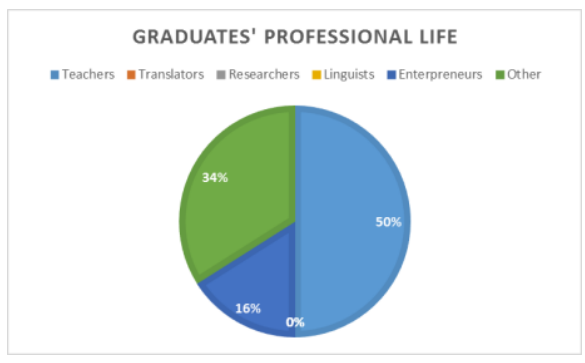

Fig 2. Alumni Professional Life

Figure 2 shows that 25 participants $(50 \%)$ work as teachers. None of them work as professional translators, researchers or linguists. Some participants claimed that they occasionally translate or do research or do language analysis. However, this was done as a parttime activity that is very infrequently done. Referring to career definition indicated in the previous section, it is not categorized as a form of career realization in this study. Surprisingly, the remaining participants were dispersed in two other categories which were not the main outcomes of this university; entrepreneurs and other. A total of 8 participants (16\%) undergone entrepreneur as their career choices and the remaining 17 people (34\%) go into the other columns.

In addition, from the interviews, this study succeeded in revealing business sectors run by alumni. These sectors turn out to be largely unrelated to the knowledge they learned when they were studying. For example, from eight self-employed participants, only two people run businesses that are directly related to learning outcomes set by the university. The rest was deemed as a business sector that has no direct connection with the learning outcomes they acquire. For example, four participants run culinary businesses and others run an online business. In the other categories, it turns out that there are many participants who work outside 
the field of ability they have. In this category there are a number of profile irrelevant professions, for example: marketing, office administrator, bank employee, insurance worker and online transportation driver.

\subsection{Learning outcomes and career connection}

The next important result was gained from the survey on learning outcomes. In this survey the alumni was asked to complete eleven question on the relevance of their learning outcomes. Their answer was considered prolific in providing the factual experience of the career realization. The questionnaires were simplified into eleven learning outcome domains; language skills, linguistics, EFL teaching, teaching methodology, research methodology, researching, academic presentation, TOEFL score, entrepreneurship, translation and literature. This domain was construed from the learning outcome statements of the English Education Department. The result of the questionnaires was displayed in the following table

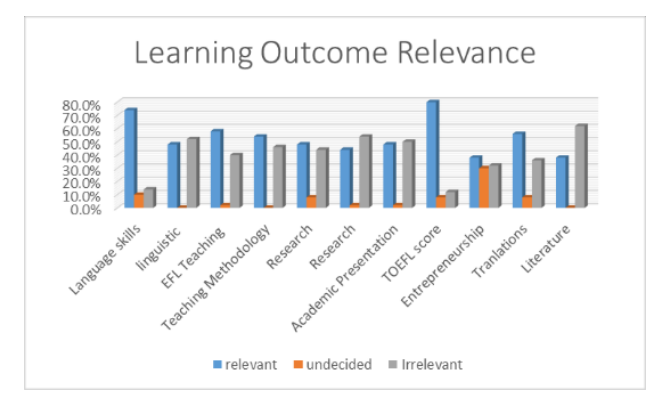

Fig 3. Graduates perspectives on learning outcomes relevance

Figure 3 illustrates the alumni perspectives on the learning outcome relevance on their careers. It was factual that the most relevant learning outcomes from the graduates' perspectives are TOEFL score (80\% respondents), language skills (74\% participants) and EFL teaching (58\% graduates). This provides beneficial information for the college or university to paying more attentions to the highly relevant learning outcomes. From the graduates' perspectives, they seem to believe the importance of those top-three learning outcomes. Conversely, the least relevant learning outcomes are literature (62\% participants), researching (54\% participants), and linguistics $(52 \%)$. Those outcomes were considered least relevant or irrelevant by the graduates in supporting and maintaining their career. However university policy makers are not supposed to react negatively to the findings. It means that they may take those findings into account to revisit and revise the existing curriculum and learning outcomes. The betterment and the refinement does not always means replacing the existing outcomes.

What the university must pay more attentions to is anticipating graduates who choose or are involved in the world of entrepreneurship and other business fields. In terms of employment absorption, this indicates a positive value because graduates from these universities are able to contribute other sectors. However, there needs to be a special review and consideration so that established learning outcomes can adapt and support the careers of graduates. 


\section{Conclusions and Suggestion}

To conclude, it is obvious that education represented by university should be more sensitive to the current professional challenge. Education is suggested to prepare more professional skill for their graduates. Frequently revisiting the curriculum and internal policy should be one of their priorities in order to keep up with the up-to-date challenge. The education process should equalize the dynamic changes in the professional life. Education policy makers are suggested to be more sensitive in providing professional through higher education.

\section{Acknowledgements}

We would like to express our gratitude to Institut Pendidikan Indonesia for providing financial support in the publication of this article.

\section{References}

[1] Noordegraaf, M.: Remaking professionals? How associations and professional education connect professionalism and organizations. Current Sociology. pp. 465-488 (2011)

[2] Watkins, J.: Educating Professionals: the changing role of UK professional associations. Journal of Education and Work. pp. 37-56 (1999)

[3] Melton, R.: Learning outcomes for higher education: Some key issues. British Journal of Educational Studies. pp. 409-425 (1996)

[4] Esteve, J. M. And Villa, J.V.: Education and work in a european framework. European Journal of Teacher Education. pp. 255-269 (1992)

[5] Coldwell, M.: Career orientations and career cultures: individual and organisational approaches to beginning teachers' careers. Teachers and Teaching. pp. 610-624 (2016)

[6] Lin-Stephens, S. Uesi, J. and Doherty, J.: Chinese returnees' conceptions of positive career outcomes after graduating from Australian universities - quantitative findings. Australian Journal of Career Development. pp. 120-129 (2015)

[7] Kim, M.: Preferences of high achieving high school students in their career development. Gifted and Talented International. pp. 65-75 (2010)

[8] Penttinen, L. Skaniakos, T. and Lairio, M.: Supporting students' pedagogical working life horizon in higher education. Teaching in Higher Education. pp. 883-894 (2013)

[9] Mathias-Williams, R. and Thomas, N.: Great expectations? The career aspirations of social work students. Social Work Education. pp. 421-435 (2002)

[10] Lee, P. C. Lee, M. J. and Dopson, L. R.: Who Influences College Students' Career Choices? An Empirical Study of Hospitality Management Students. Journal of Hospitality \& Tourism Education. pp. 1-13 (2018)

[11] Barclay McKeown, S. and Ercikan, K.: Student perceptions about their general learning outcomes: do they add up?. AERA Open. pp. 1-20 (2017)

[12] Danziger, N. and Eden, Y.: Student career aspirations and perceptions: The case of Israeli accounting students. Accounting Education. pp. 113-134 (2006)

[13] Liu, O. L., Bridgeman, B. and Adler, R. M.: Measuring Learning Outcomes in Higher Education: Motivation Matters. Educational Researcher. pp. 352-362 (2012) 